\title{
Analysis and Design of PBL-Based Mathematics Students Worksheet to Improve Critical Thinking Skills
}

\author{
Muhammad Syakir Y Hairun ${ }^{1}$, Suparman",", Yahya Hairun ${ }^{2}$ \\ ${ }^{1}$ Department of Mathematics Education, Postgraduate Program, Universitas Ahmad Dahlan, Indonesia \\ ${ }^{2}$ Department of Mathematics Education, Khairun University, Indonesia
}

Received February 24, 2020; Revised April 16, 2020; Accepted April 27, 2020

Copyright $\mathrm{C} 2020$ by authors, all rights reserved. Authors agree that this article remains permanently open access under the terms of the Creative Commons Attribution License 4.0 International License

\begin{abstract}
Critical thinking needs to be integrated into the learning of mathematics in the 21 st century and the industrial revolution 4.0. A learning model that supports the inculcation of critical thinking skills is problem-based. To implement the problem-based learning model, appropriate learning resources are needed. However, existing learning resources do not yet support the development of students' critical thinking skills. This study aims to analyze the needs of learning resources and then design student worksheets for problem-based learning models to improve critical thinking skills. This study used descriptive qualitative method. The subjects of the study were students of Muhammadiyah Middle School. The objects of research are essential skills of thinking, problem-based learning models, and student worksheets. Data collection instruments used interview guidelines, questionnaires, and validation sheets. The data obtained were analyzed using the Miles-Huberman model, which consisted of data reduction, data presentation, and concluding. This study produces an analysis of the needs of learning resources that are appropriate to the characteristics of students, curriculum, and subject matter. The study also provided a valid student worksheet design. This student worksheet design can be used by teachers who want to develop student worksheets that fit the problem-based learning model. This student worksheet design is also designed to improve students' critical thinking skills.
\end{abstract}

Keywords Critical Thinking, Students Worksheet, Problem-Based Learning

\section{Introduction}

Today, there are so many challenges to face in the $21 \mathrm{st}$ century or commonly referred to as the industrial revolution of 4.0 [1]. An individual needs to equip himself to be able to survive with the development of an increasingly advanced era now. Critical thinking is required to solve complex problems in everyday life [2]. Critical thinking skill is an indispensable skill. This is due to the increasingly complex problems caused by rapid technological developments and social movements, so educators must teach these thinking skills to their students so that they can be equipped to become successful citizens in the future [3]. The progress of its education also measures the quality of a country. A nation is said to be advanced if it has a good quality education. This makes education compulsory for every individual. Individuals who have good quality critical thinking are needed to meet the challenges in life that continue to increase [4].

Critical thinking is a term associated with high-level reasoning that is usually characterized by good analysis and consideration [5]. Critical thinking skills are very important for students because they can influence the development of students' thinking [6]. Critical thinking skills are very important skills and function effectively both in life, work, and other aspects of life [7]. Most people can develop critical thinking skills in every aspect of life [7]. Most people can develop their critical thinking skills which can help them [8]. The Indonesian government made improvements to improve the quality of education. However, education in Indonesia remains stagnant and has not shown significant changes. This can be seen from the results of the PISA-OECD (Organization Program for Economic Cooperation and Development) in 2015, Indonesia ranked 63 out of a total of 72 countries participating in the event. Indonesia gets 386 out of 500, which becomes international standards [9]. Based on these results, it can be seen that education in Indonesia still needs to be improved.

Most students are not easy to solve mathematical problems [10]. One factor of the low value of Indonesian mathematics is the low ability to think critically. Critical thinking has six indicators, namely: interpretation, analysis, inference, evaluation, explanation, self-regulation [11]. Critical thinking is the realization of 
high-level thinking. Critical thinking is seen as the ability to think in comparing two or more information [12]. Critical thinking can be the basis for teachers and students to participate and making decisions [13]. The ability to think critically is needed to work on HOTS problems.

Critical thinking is difficult and not easy to develop automatically. To develop, it requires practice and effort [14]. This is due to the absence of models and teaching materials that can be used as tools that can support teachers in realizing appropriate teaching. This resulted in the need for a learning model that not only could improve students' thinking skills, but also had to be able to attract motivation so they wanted to follow the teaching and learning process that was held. Problem-based learning can be a solution. The problem-Based Learning model is one of the learning models that can be used [15]. Problem-based learning is special learning because the focus of learning is the problem, not the subject [16]. Problem-based learning focuses on learning experiences in real life [17]. Problem-Based Learning is effective in achieving a general approach. The general approach is the first stage of critical thinking [18]. Problem-based learning is student-centered learning. The student can learn about the subject by trying to find solutions to open problems [18]. The pedagogic approach in Problem-Based Learning involves students building knowledge and collaborates with groups to solve questions [19]. Thomas said problem-based learning as a type of learning that involves problems and provides an opportunity to design investigative activities, using problem-solving to arrive at conclusions [20]. Problem-Based Learning models can be one way to improve critical thinking skills [21].

Problem-Based Learning authenticity involves students learning information using the same methods used to remember and used in future situations and assesses learning by showing understanding, not just acquisition. Problem-Based Learning models, students use a "trigger" to determine their own learning goals [22]. The thing that needs to be considered by educators when using Problem-Based Learning is the process of discussion and the use of various triggers for various problems [17]. The sequence in Problem-Based Learning is very important for student learning processes [23]. Problem-Based Learning phases are important to influence student learning outcomes [24]. The student considers Problem-Based Learning as interesting learning and it motivates them to learn [25]. Problem-Based Learning was built to promote the various learning outcomes and objectives needed, including (1) helping students build a flexible knowledge base, (2) helping students become effective collaborators, (3) enhancing the ability to solve effective problems, (4) motivating students to learn intrinsically, and (5) developing independent learning skills [25]. Arends said the steps of the Problem-Based Learning model were (1) students' orientation towards problems, (2) Arranging students to study, (3) Assisting independent and group investigations, (4) Developing and presenting artifacts and exhibitions, (5) Analyzing and evaluating the problem-solving process, also Tan said the Problem-Based Learning Characteristics are as follows: 1) Asking questions or problems, making questions related to problems and allowing various solutions to solve problems. 2) Focus on interdisciplinary relationships, student reviews about problems from various subjects. 3) Authentic requests, students must analyze, build problems, develop hypotheses, and make predictions, collect, and analyze information, conduct experiments, and draw conclusions. 4) Produce products and publish, demanding students to produce certain products in the form of real work or demonstrations that represent solutions to the problems they find. 5) Collaboration, joint student work, most often form pairs in small groups [26]. Problem-Based Learning can be applied to learning in junior high school [27]. Therefore the objectives of this research are to develop Problem-Based Learning based student worksheet to improve student critical thinking ability.

\section{Method}

As in [28-32], this research and development use the ADDIE (Analysis, Design, Development, Implementation, Evaluation) model. ADDIE is a design guideline that is often used to create effective designs [33]. The ADDIE stages are presented in Figure 1.

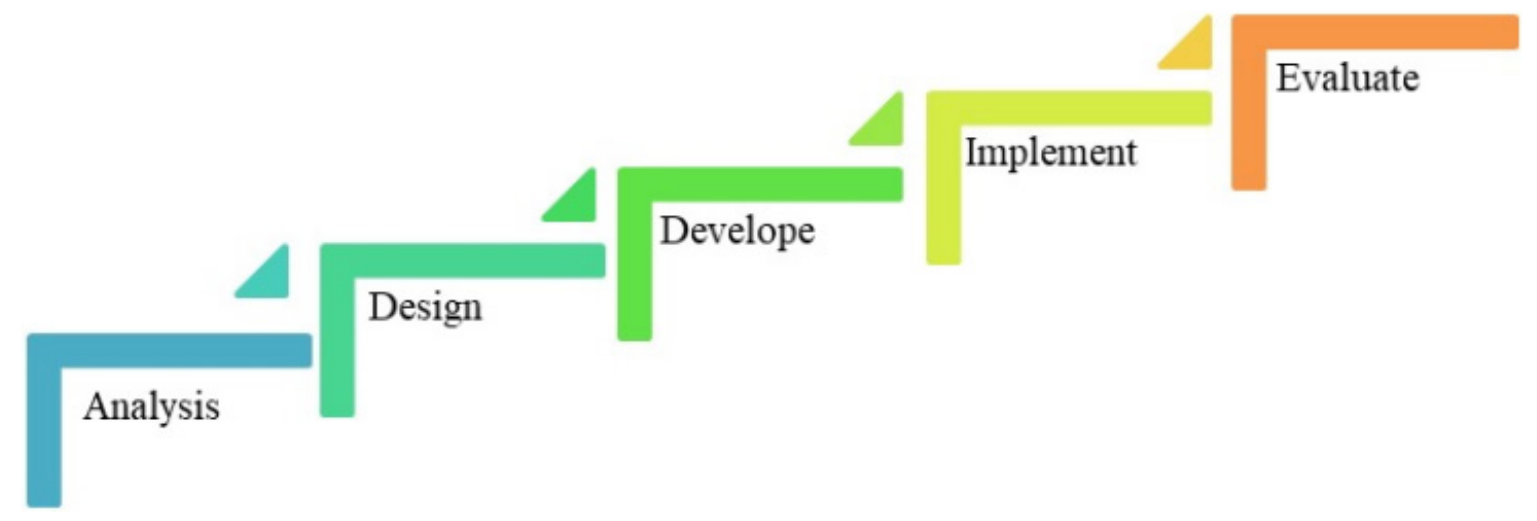

Figure 1. ADDIE [34] 
This research is limited to the analysis and design stages. Interviews with teachers were conducted to find out data about student needs, the problem-based learning model, learning models, and teaching materials used by teachers and students in learning. The data obtained is used as a reference in the development of students worksheet based on the problem-based learning model.

Student worksheet which was developed in this research is used as a teaching language that can improve students' critical thinking skills. The subjects in this study were 8th-grade junior high school teachers in Muhammadiyah Bantul Yogyakarta 2019/2020 academic year. Data collection instruments include interviews.

\section{Results and Discussion}

\subsection{Analysis}

This stage is part of the background why so this teaching material is developed. At this stage, there are 2 stages, namely performance analysis and needs analysis. Based on observations and interviews there is some information. The results of this study received that information:

1) Teaching materials used are still conventional

2) The learning model used is still the same; the teacher has not used a learning model that can improve students' critical thinking skills.

3) In terms of curriculum, according to what is determined, that is, each material is displayed following $\mathrm{KI}$ and $\mathrm{KD}$ along with its indicators.

4) Unavailability of integrated student worksheet to help teachers improve students' critical thinking abilities.
5) Lack of students' interest to participate in the teaching and learning process so that teachers find it difficult to use certain models or methods because they must be adapted to the conditions of students when teaching.

6) Teachers need teaching materials such as student worksheet and immigration learning models that can improve students' critical thinking skills.

Based on the results of the study, the researcher concludes that students and teachers need teaching materials such as student worksheet that can attract students' interests and can be used by teachers so students can be motivated in following the teaching and learning process. Teachers and students need students worksheet based on Problem-based learning.

\subsection{Design}

Teaching material design is based on the results of needs analysis. The teaching material used is student worksheet based on Problem-based learning [35]. Student worksheet design consists of several components, namely cover, foreword, core competencies, basic competencies, instructions for using students worksheet, the design of the students worksheet can be seen in the following image.

\subsubsection{Cover Design}

A cover design includes the title of student worksheet and also includes Subjects, Circle Material and Problem-based learning models. Cover design can be seen in Figure 2. 


\title{
MATEMATIKA
}

\author{
LEMBAR KERJA PESERTA DIDIK \\ BERBASIS PROBLEM BASED \\ LEARNING
}

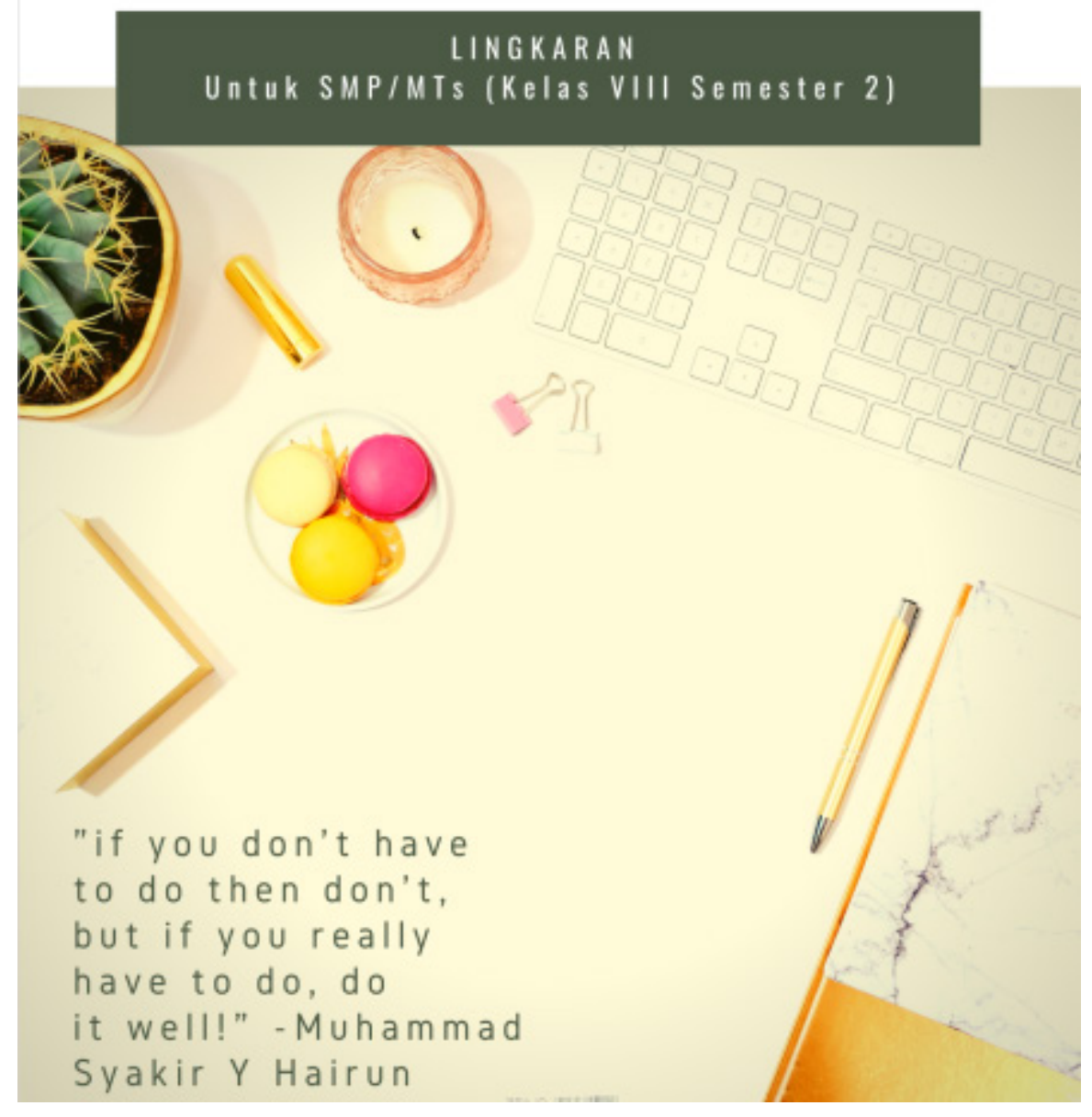

Figure 2. Cover Design

\subsubsection{Foreword}

Preface containing the author's thanks to the parties involved can be seen in Figure 3. 


\section{KATA PENGANTAR}

Puji syukur kita panjatkan kehadirat Allah SWT yang telah memberikan Rahmat dan hidayahnya

kepada penulis, sehingga penulis dapat menyelesaikan tugas ujian akhir semester yang berjudul

"Lkpd Matematika berbasis problem based learning Smp Kelas Viii". Tentunya dalam penyelesaian tugas ini masih penulis sadar akan kekurangan dalam penyelesaian tugas Ini.,

Tentunya manusia tidak luput dari kesalahan dan kehilafan, oleh karena itu penulis mengharapkan saran dan kritik yang membangun, apabila dalam penyelesaian tugas ini terdapat kesalahan. Penulis mengucapkan terima kasih kapada dosen pengampuh yang dimana telah memberikan pembelajaran kepada penulis sehingga penulis bisa membuat tugas ini.

Figure 3. Foreword

\subsubsection{Basic Competencies and Core Competencies}

Description of Basic Competencies and Core Competencies and indicators of competency achievement. Core competencies and basic competencies can be seen in Figure 4. 


\section{KOMPETENSI DASAR}

3.7 Menurukan rumus untuk menentukan rumus keliling dan luas lingkaran yang dihubungkan dengan masalah kontekstual

4.7 Menyelesaikan masalah kontekstual yang berkaitan dengan keliling dan luas lingkaran

\section{Indikator Pencapaian Kompetensi}

3.7.1 Menurunkan rumus untuk menentukan keliling lingkaran mengguakan masalah kontekstual

3.7.2 Menurunkan rumus untuk menentukan luas lingkaran mengguakan masalah kontekstual

4.7.1 Menyelesaikan msalah kontekstual yang berkaitan dengan keliling lingkaran dan luas lingkaran

\section{Problem Based LearnIng (PBL)

Figure 4. Basic Competencies and Core Competencies

\subsubsection{Instructions for use}

Instructions for using student worksheet. Shown design drawings which contain steps for using student worksheet, and icons that show indicators of Problem-based learning and problem-solving can be seen in figure 5 . 


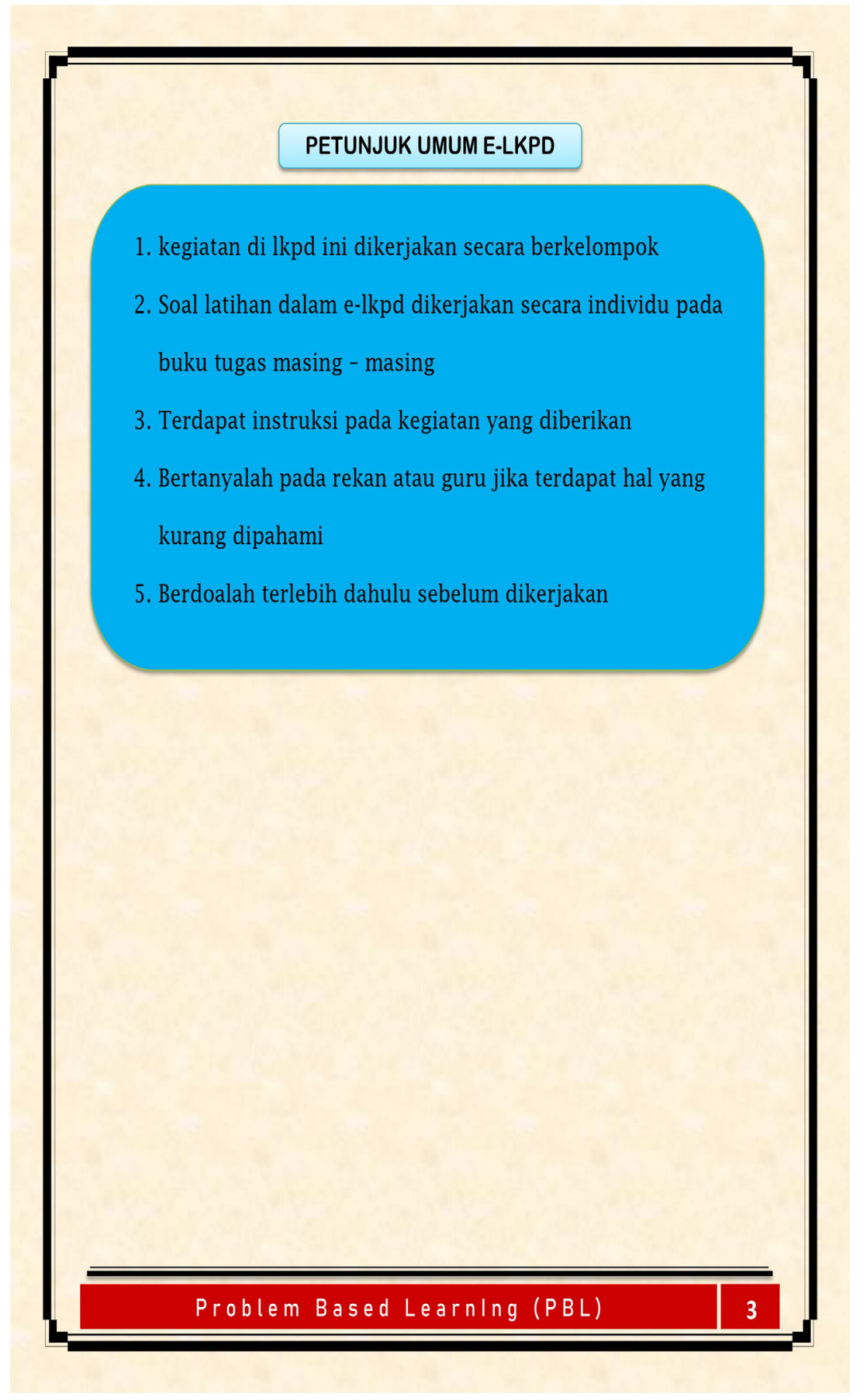

Figure 5. Instructions for use

Table 1. Suggestions and Comments

\begin{tabular}{|l|l|l|}
\hline No & Suggestions and comments & Improvement \\
\hline 1 & $\begin{array}{l}\text { On the cover of the image used } \\
\text { to be the dominant white color. } \\
\text { Not stated in what semester will } \\
\text { be used, as well as school } \\
\text { institutions that use SMP / Mts }\end{array}$ & Already repaired \\
\hline 2 & $\begin{array}{l}\text { Writing the table of contents is } \\
\text { not complete }\end{array}$ & Already repaired \\
\hline 3 & $\begin{array}{l}\text { writing the title does not use bold } \\
\text { letters }\end{array}$ & Already repaired \\
\hline
\end{tabular}

To develop the students worksheet design, we need to find out whether the students worksheet is to be developed, therefore the design of the students worksheet is validated by experts and provides comments and suggestions for improvement. Student worksheet has been assessed as feasible by two mathematics teachers. The validators of the student worksheet design were Lalu Indar Putra Anggara and also Zunita Hernawati which consisted of mathematics teachers. Suggestions and comments for improving student worksheet can be seen in Table 1 .

Based on the table 1, it can be concluded that students worksheet is feasible to use. However, there have been 
several revisions. Some input and suggestions from material and media experts that have been summarized can be seen in the displayed images. Some parts of student worksheet that have been improved after receiving input and suggestions from the validator are as shown in Figure [6-8]:

\section{BEFORE}

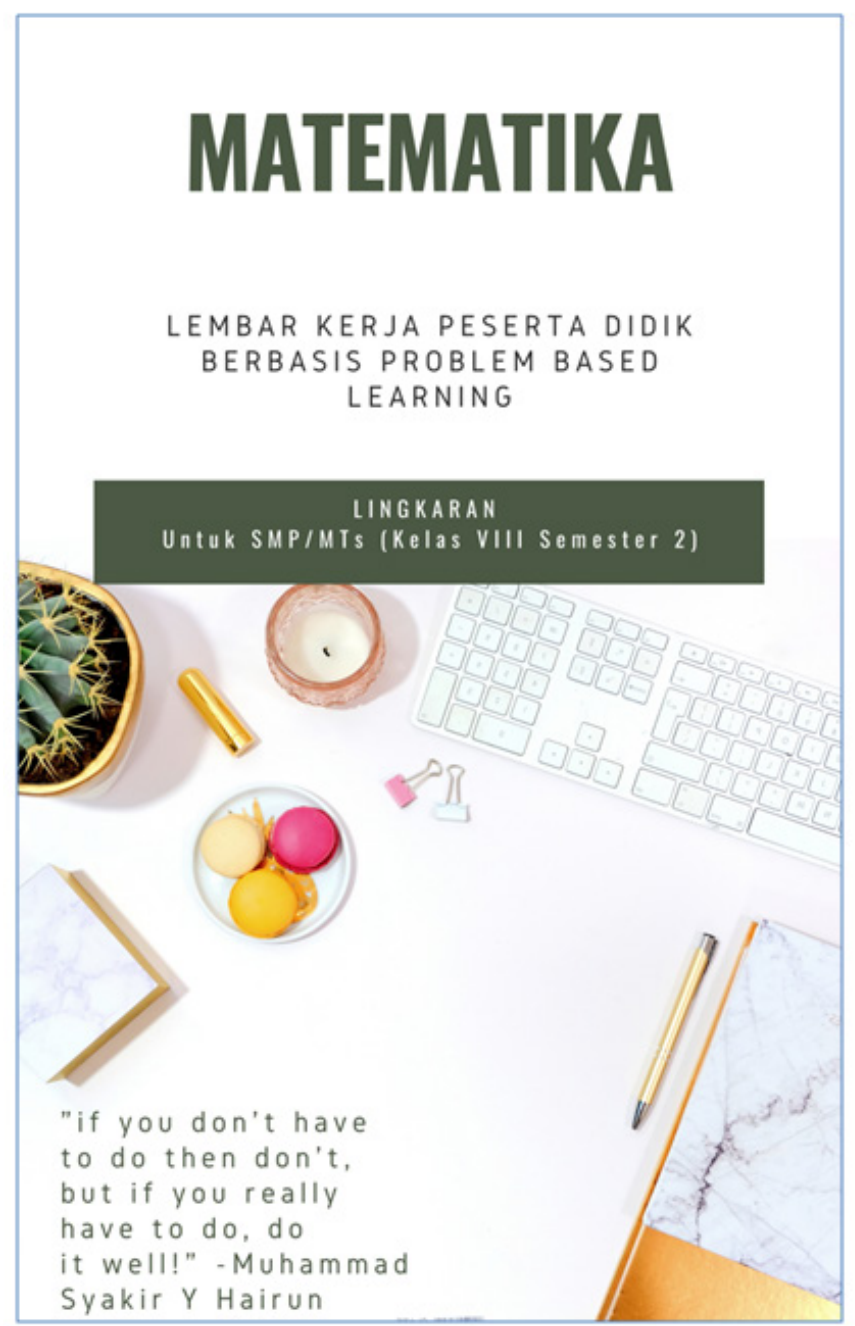

AFTER

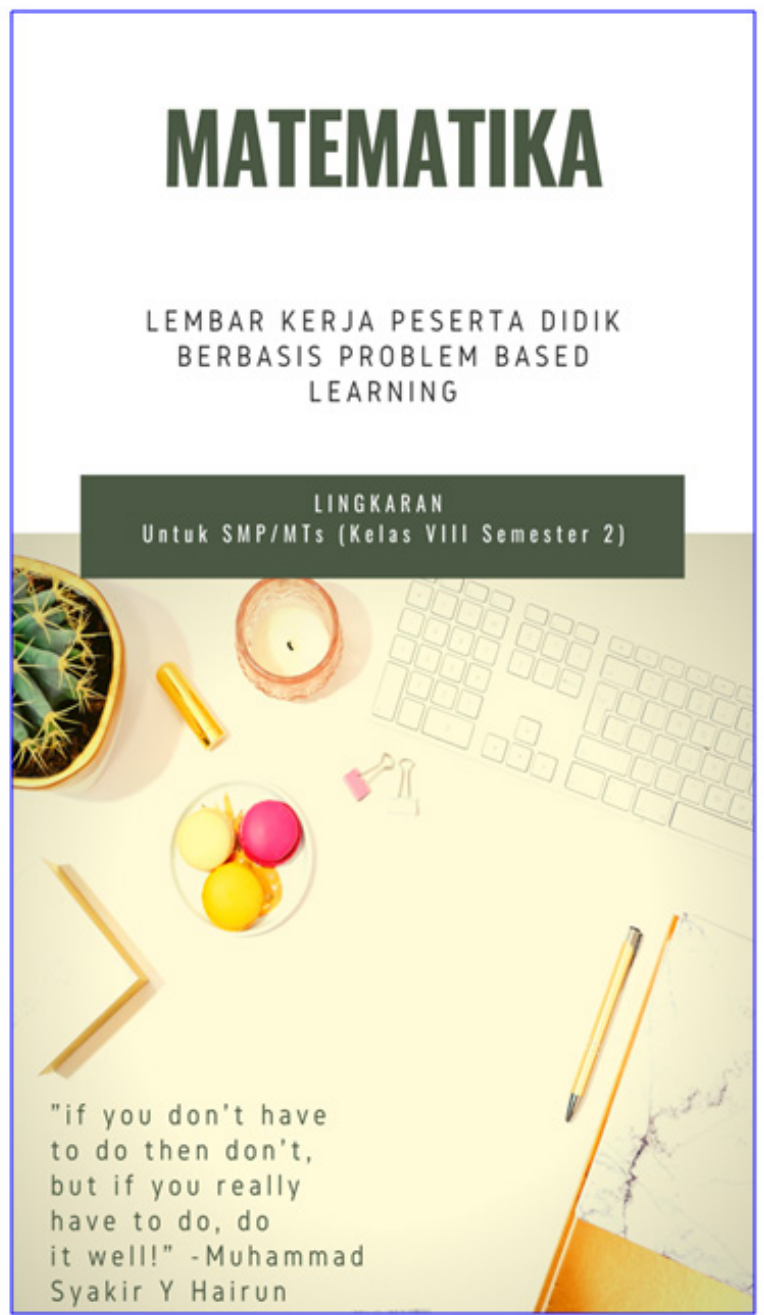

Figure 6. Cover Repair 


\section{BEFORE}

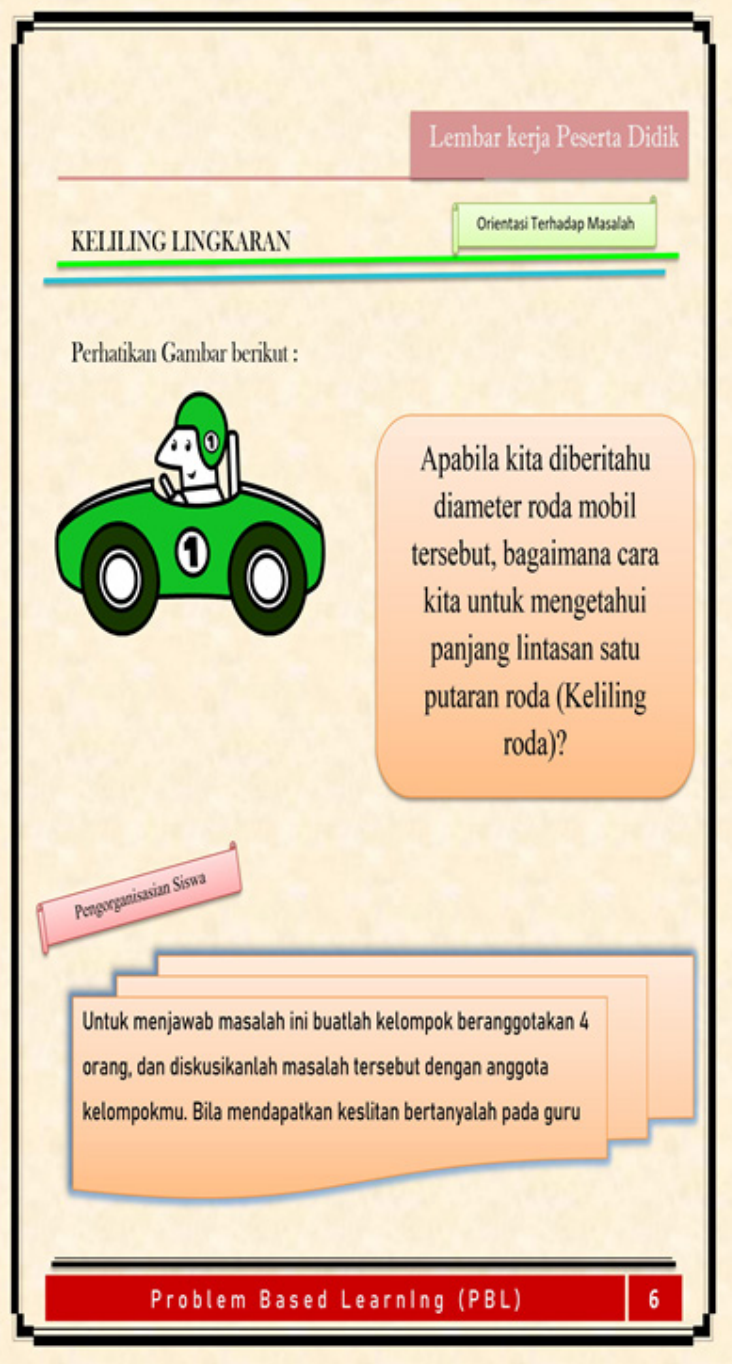

AFTER

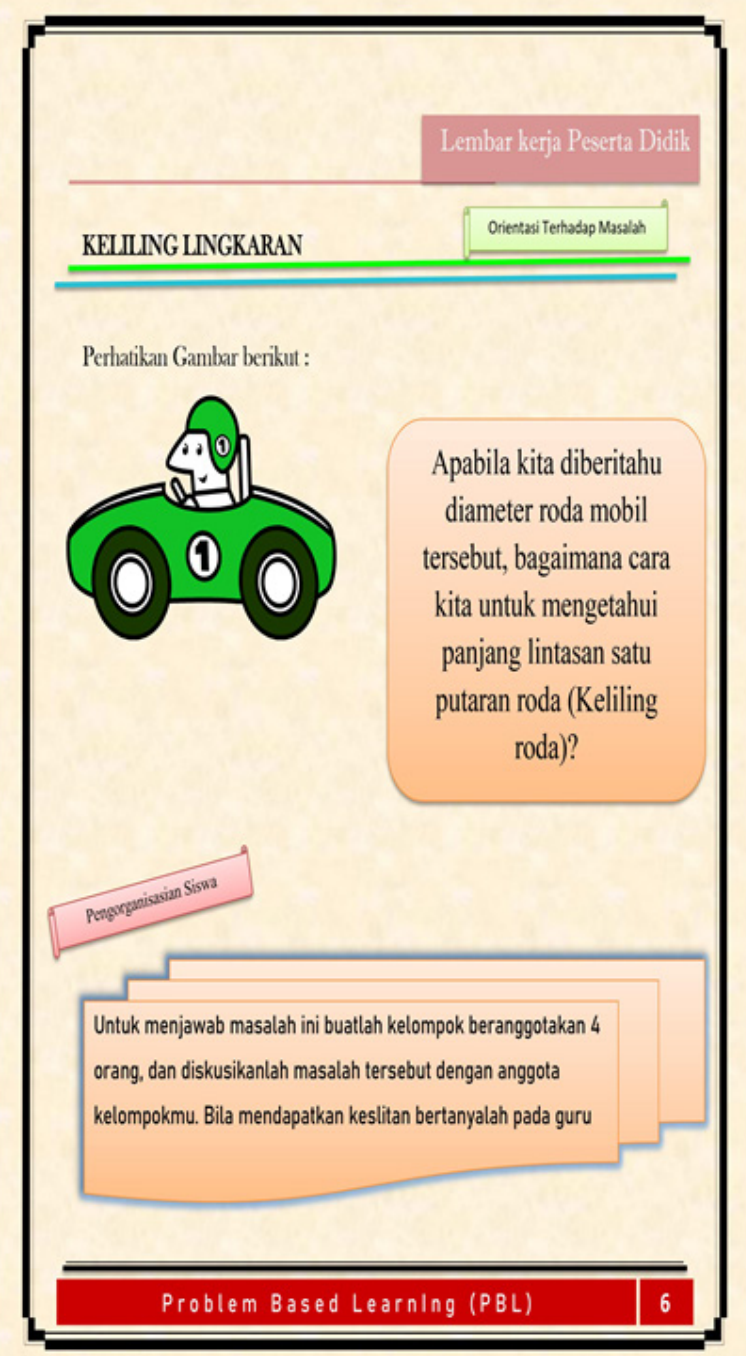

Figure 7. Table of Contents Repair 


\section{BEFORE}

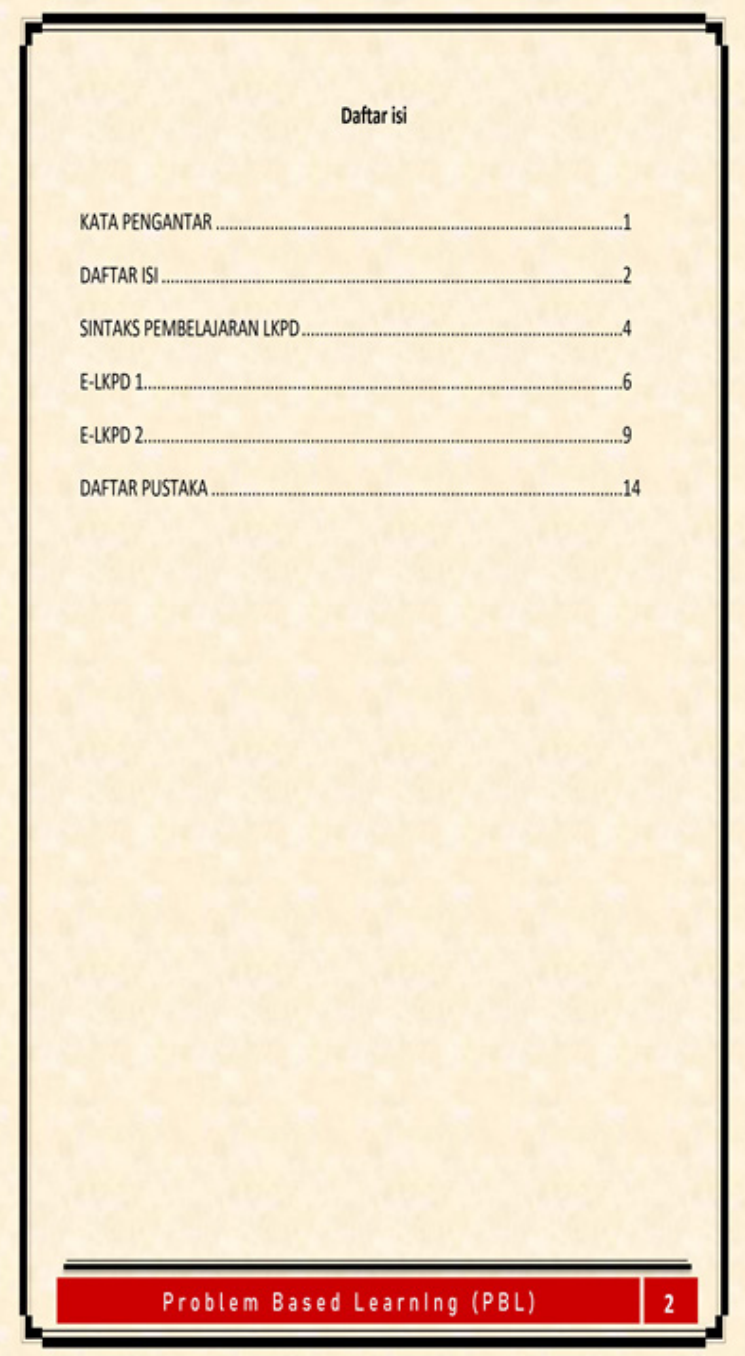

AFTER

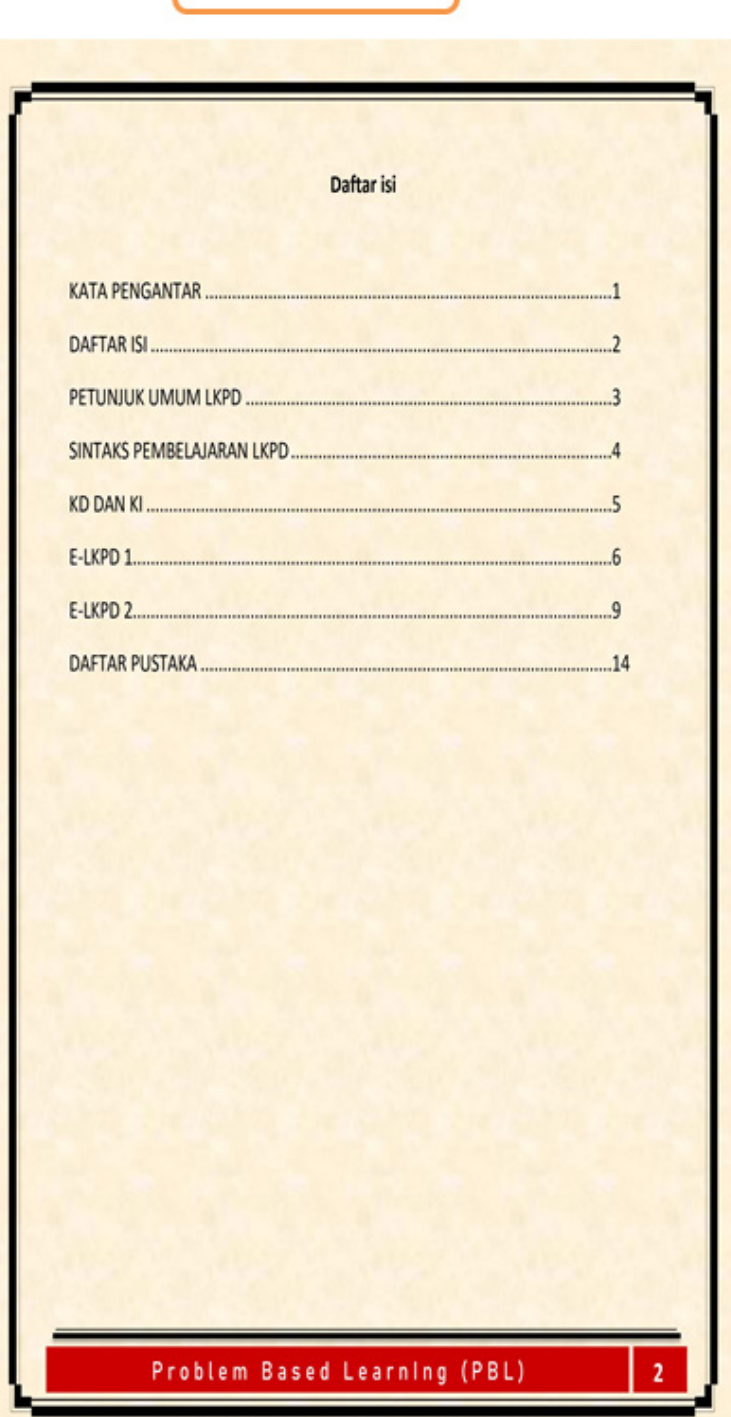

Figure 8. Revision of Title

Table 2. Design Assessment Results

\begin{tabular}{|c|c|c|c|}
\hline No & Validator & Score & Category \\
\hline 1 & Lalu Indar Anggara & 77 & Good \\
\hline 2 & Zunita Rahmaniawati & 80 & Good \\
\hline & Total Score & 157 & \\
\hline & Average Score & 78.5 & Good \\
\hline
\end{tabular}

Enter along with suggestions from the validators that have been revised. The results of the questionnaire calculations given to the validator regarding the developed designs can be seen in Table 2 .

Based on table 2, the average score obtained from the assessment of media experts is 78.5. So it can be concluded that the learning media are in a good category. Learner worksheets have been validated by the validator and declared eligible with revisions. At this stage, products that have been developed and met the eligibility and effectiveness criteria are given to the school that will be used as a research site. This stage is carried out to ensure students achieve their goals in learning outcomes and can improve students' creative thinking abilities. At this stage, a process to provide value to the learning program has been developed. Students will be evaluated to the extent to which students can learn. The material so that can develop students' critical thinking. The development, implementation, and evaluation stages are further research. The linkages between problem-based learning models and student activities in the student worksheets are presented in figure 9. Figure 9 also shows the linkages between student worksheets that are designed to bring up indicators of students critical thinking skills through student activities.

Figure 9 explains the relationship between 
Problem-Based Learning model syntax, student activities and indicators of critical thinking skills. The stages of the Problem-Based Learning model include: the first stage is the introduction of problems to students, the second stage is organizing students to assignments related to the problem, and the third stage is guiding students to gather information needed to solve existing problems. The first, second, and third stages are implemented in the form of student activities to gather information appropriate to the teacher's directions for solving existing problems. Through this activity, students can understand and interpret existing problems, so that the first indicator of critical thinking skills appears in students. The fourth stage is implemented in the form of student activities to develop and present the work. Through this activity, students solve existing problems and present the results of problem solving that has been done, so that the second and third indicators of critical thinking skills emerge in students. This can be seen when students are able to analyze and infer to be able to solve existing problems, which will then be developed and presented the results of the problem solving that has been done. The fifth stage is implemented in the form of student activities to analyze and evaluate the problem solving process that has been done. Through this activity, students provide reflection and evaluate the material they have learned, so that the fourth, fifth, and sixth indicators of critical thinking skills emerge in students. This can be seen when students evaluate, explain, and review lessons.

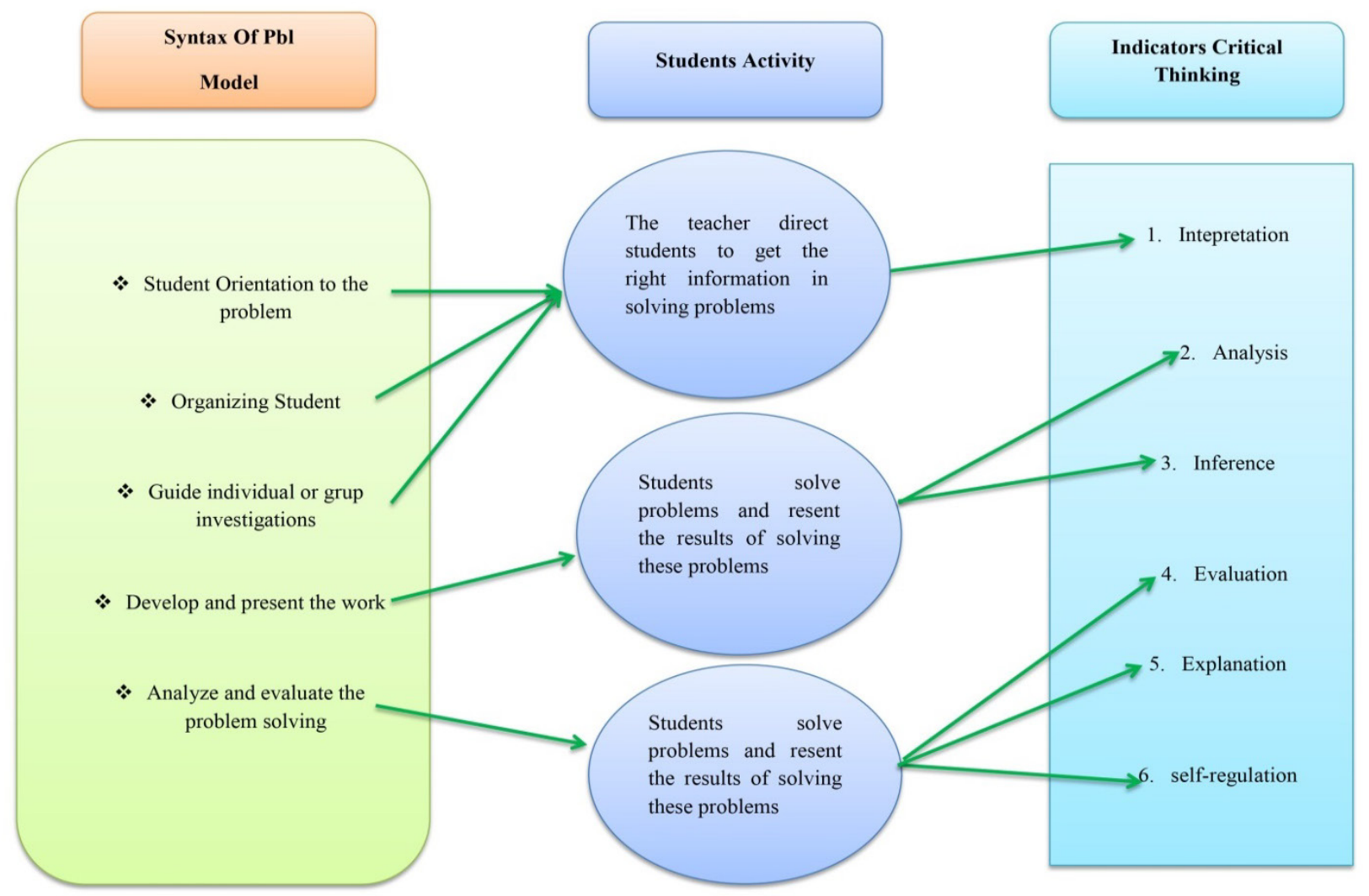

Figure 9. The linked between problem-based learning models and students activity 


\section{Conclusions}

This study produces an analysis of the needs of learning resources that are appropriate to the characteristics of students, curriculum, and material. Based on needs analysis, this study also produced a student worksheet design that facilitated the development of critical thinking skills. The design developed is integrated with the problem based learning model. Research can be continued at the development, implementation and evaluation stages.

\section{Acknowledgements}

Thank you to the Muhammadiyah Middle School in Banguntapan for providing data for research and reviewers who have helped in improving the quality of this manuscript.

\section{REFERENCES}

[1] A. Triyono and Suparman, "Inquiry-Based Worksheet Design to Improve Critical Thinking of Students in Indonesia", International Journal of Scientific and Technology Research Vol. 8, Issue 10, pp. 1183-1187, 2019.

[2] I. Andriani and Suparman, "Design of Module to Increasing Critical Thinking Ability for Seventh Grade Students", International Journal of Scientific and Technology Research Vol. 8, Issue 12, pp. 853-856, 2019.

[3] K. Ulger, "The effect of problem-based learning on the creative thinking and critical thinking disposition of students in visual arts education, "interdisciplinary Journal of Problem-Based Learning, Vol.12, No.1, 2018

[4] A. Taghinezhad, Riasati, M. J. Riasati, E. Rassael, and F. Behjat, "The impact of teaching critical thinking on Iranian students' writing performance and their critical thinking dispositions," BRAIN-Broad Research in Artificial Intelligence and Neuroscience (Special Issue on Educational Psychology), Vol. 9, No. 1, pp. 64-80, 2018 ?

[5] S. Y. Seventika, Y.L. Sukestiyarno, and S. Mariani, "Critical thinking analysis based on Facione (2015) - Angelo (1995) logical mathematics material of vocational high school (VHS)," Journal of Physics: Conference Series. 983, (ICMSE), 2018.

[6] S. Mahanal, S. Zubaidah, I.D. Sumiati, T. M. Sari, and N. Ismirawati, "RICOSRE: A learning model to develop critical thinking skills for students with different academic abilities,'International Journal of Instruction, Vol. 12, No. 2, pp. 417-434, 2019.

[7] S. J. Rahayu, Sukarmin, and P. Karyanto, "Analysis of Junior High School Students' Critical Thinking Skills Profile in Surakarta," Journal of Physics: Conference Series, Vol. 1233, No. 1, 2019.

[8] J. Kleinig, "Trust and critical thinking," Educational
Philosophy and Theory, Vol. 50, No. 2, pp. 133-143, 2018.

[9] OECD. (2016). PISA 2015. Resul Focus. www.oecd.org/pis a

[10] N. Puspandari and Suparman, "Design Of Mathematics Learning Multimedia Base On PBL Model To Improve Student's Creative Thinking Skill", International Journal of Scientific and Technology Research Vol. 8, Issue 12, pp. 486-489, 2019.

[11] P.a. Facione, "Critical Thinking: What It Is and Why It Counts. Insight Assessment, pp. 1-28. 2011.

[12] Rasiman, "Leveling of Students' Critical Ability in Solving Mathematics," International Journal of Education and Researrch, Vol. 3, No. 4, pp. 307-318, 2015

[13] L.E. Jaffe, D. Lindell, A.M. Sullivan, G.C. Huang, "Perspectives on Medical Education Clear skies ahead: optimizing the learning environment for critical thinking from a qualitative analysis of interviews with expert teachers," Sep. 2019

[14] A Prasetyaningtyas and Suparman, "Student's Worksheet Design to Improving problem-solving ability of Seventh Grade with PBL", International Journal of Scientific and Technology Research Vol. 8, Issue 12, pp. 2845-2849, 2019.

[15] A.M. Persky, M.S. Medina, A.N. Castleberry, "Developing critical thinking skills in pharmacy students," American Journal of Pharmaceutical Education, Vol. 83, No. 2, pp. $161-170,2019$

[16] D. A. A. Casas, "Critical thinking development by using the implicit content of songs 1 Desarrollo del pensamiento crítico a través del uso del contenido implícito de canciones," Enletawa Journal, Vol. 11, No. 1, pp. 13-32, 2018

[17] V.F.C. Servant-Miklos, "The Harvard Connection: How the Case Method Spawned Problem-Based Learning at McMaster University," Health Professions Education, Vol. 5. No. 3, pp. 163-171, 2019

[18] R. Phungsuk, C. Viriyavejakul, and T. Ratanaolarn, "Development of a problem-based learning model via a virtual learning environment.," Kasetsart Journal of Social Sciences, Vol. 38, No. 3, pp. 297-306, 2017.

[19] L. Balan, T. Yuen, and M. Mehrtash, "Problem-Based Learning Strategy for CAD Software Using Free-Choice and Open-Ended Group Projects,'Procedia Manufacturing, Vol. 32, pp. 339-347, 2019.

[20] B. Aidoo, S.K. Boateng, P.S. Kissi, I. Ofori, "Effect of Problem-Based Learning on Student Achievements in Chemistry," education and practice journal, Vol. 7, No. 3, pp. 103-108, 2016

[21] H.C. Chang, N.Y. Wang, W.R. Ko, Y.T. Yu, L.Y. Lin, and H.F. Tsai, "The effectiveness of clinical problem-based learning model of medico-jurisprudence education on general law knowledge for Obstetrics/Gynecological interns," Taiwanese Journal of Obstetrics and Gynecology, Vol. 56, No. 3, pp. 325-330.

[22] J. Wosinski, A.E. Belcher, Dürrenberger, Y. Allin, A.C. Stormacq, C. Gerson, and Linda," Nurse Education Today, Vol. 60, pp. 67-74, Jul. 2017. 
[23] E.H.J. Yew, and K. Goh, "Problem-Based Learning: An Overview of its Process and Impact on Learning," Health Professions Education, Vol. 2, No. 2, pp. 75-79, 2016.

[24] S.N.H. Hadie, and M.S.B. Yusoff, "Assessing the validity of the cognitive load scale in a problem-based learning setting, "Journal of Taibah University Medical Sciences, Vol. 11, No. 3, pp. 194-202, 2016.

[25] R.R. Sihaloho, Sahyar, and E.M. Ginting, "Effect of Problem Based Learning (PBL) Model toward Student's Creative Thinking and Problem Solving Ability inSenior High School,"(IOSR-JRME), Vol. 7, No. 4, pp. 11-18, 2017

[26] M. Hussain, S. Sahudin, A. Samah, N.H. Anuar, and N. Khaizan, "Students perception of an industry based approach problem based learning (PBL) and their performance in drug delivery courses, "Saudi Pharmaceutical Journal, Vol. 27, No. 2, pp. 274-282, 2019

[27] S. Nursolekah and Suparman, "Design of Mathematics Learning Module Based on Problem Based Learning to Improve Critical Thinking Ability Students ", International Journal of Scientific and Technology Research Vol. 8, Issue 12, pp. 2609-2516, 2019

[28] B.P. Syafina And Suparman, "Designing Student Worksheets To Improve Critical Thinking Ability Based On Problem Based Learning" International Journal of Scientific \& Technology Research Volume 8, Issue 10, pp 1194-1199, October 2019

[29] S. Suprotun and Suparman, "Development Learning Design Lift Material Flap With Character Education To Improve Problem Solving Abilities", International Journal of
Scientific and Technology Research Vol. 8, Issue 12, pp. 2806-2810, 2019

[30] Suhendri and Suparman, "Development Mathematics Modules Based on Guided Discovery Learning to Improve Creativity Skills of Blind Students," International Journal of Scientific \& Technology Research, Vol. 8, Issue 10, pp. 1169-1173, 2019.

[31] Isnaepi and Suparman, "Design of Moodle-Based Mathematics Learning to Improve Spatial Ability for Class XII High School Students," International Journal of Scientific \& Technology Research, Vol. 8, Issue 10, pp. 1174-1177, 2019.

[32] P. Angraini and Suparman, Students Worksheet Design On Geometry For Seventh Grade Students With Rme Approach, International Journal of Scientific \& Technology Research, Vol. 8, No.10, 1155-1158, 2019.

[33] A. Sulistyaningsih, Suparman, and E. Rakhmawati, "Mathematics Module Development Design Based On PBL To Improve Mathematics Problem-Solving Ability", International Journal of Scientific and Technology Research Vol. 8, Issue 11, pp. 2508-2516, 2019.

[34] A. Rahmi and Suparman, "Mathematical Module Based on CTL Approach to Increase Learning Motivation and 4C Skills", International Journal of Scientific and Technology Research Vol. 8, Issue 12, pp. 1303-1309, 2019.

[35] N.H. Marhaeni and Suparman, "Design of PBL Student's Worksheet In The Properties of Determinants and Matrix Inversions," International Journal of Scientific \& Technology Research, Vol. 8, Issue 12, pp. 847-852, 2019 